\title{
Other Minor Writings
}

Dickens wrote extensively for his various periodicals; and while much of his work was collected (in, for example, The Uncommercial Traveller) much more was uncollected. The question is complicated by the fact that many contributions had a joint authorship and by Dickens' editorial practice of rewriting the articles submitted by some of his contributors. Anne Lohrli's useful book on Household Words (Toronto: University of Toronto Press, 1973) makes clear Dickens' contributions to that periodical. On Dickens as editor, see various articles by Gerald G. Grubb (for example, Studies in Philology, XL, I943; ibid., XLII, 1945); also Philip Collins in Dickensian, LII, 1956, and LXI, 1965; and in Review of English Literature, II, I96 r. For various collections of Dickens' journalism, see pp. 313-14.

Among other items too numerous to list completely, the following may be singled out for mention:

Sunday under Three Heads ( 1836$)$. Illustrated by Phiz.

Sketches of Young Gentlemen (1838). Illustrated by Phiz.

Memoirs of Joseph Grimaldi (1838). Dickens abridged the text and added a preface. Illustrated by Cruikshank.

Sketches of Young Couples (1840). Illustrated by Phiz.

An Appeal to Fallen Women ( 1847 ). Pamphlet written in connexion with Miss Burdett Coutts' charitable efforts.

Letters to The Times on public executions, I 4 and I9 January 1849; reprinted as a pamphlet ( 1849 ).

The Life of Our Lord (1849, I934). Written for his own children and not intended for publication.

$A$ Child's History of England (three volumes, 1852-4). Originally serialized in Household Words, $185^{1-3}$. 